\title{
Changes in the dynamic modulus of elasticity and bending properties of railroad ties after 20 years of service in Taiwan
}

\author{
Cheng-Jung Lin ${ }^{\mathrm{a}}$, Te-Hsin Yang ${ }^{\mathrm{b}, *}$, Dong-Zhi Zhang ${ }^{\mathrm{b}}$, Song-Yung Wang ${ }^{\mathrm{b}}$, Far-Ching Lin ${ }^{\mathrm{b}}$ \\ ${ }^{a}$ Division of Forest Utilization, Taiwan Forestry Research Institute, 53 Nan-Hai Rd., Taipei 100, Taiwan \\ ${ }^{\mathrm{b}}$ School of Forestry and Resource Conservation, National Taiwan University, No. 1 Roosevelt Rd., Sec. 4, Taipei 106, Taiwan
}

Received 2 September 2005; received in revised form 8 November 2005; accepted 25 November 2005

\begin{abstract}
An ultrasonic-wave technique and transverse vibration nondestructive evaluation methods were used to evaluate the dynamic modulus of elasticity and bending properties of wood from railroad ties of creosote treated from 7 species of wood removed from service after 20 years. Two NDE techniques and static bending tests were conducted on railroad ties, and lumber and specimens subsequently cut from the ties. Regression analyses gave a reasonably useful correlation between the ultrasonic-wave-based dynamic modulus of elasticity of the ties and lumber and the corresponding flexural properties of lumber and small clear specimens determined by 2 NDE techniques and static bending techniques, respectively. The results showed that wood from the creosote-treated railroad ties removed after years of service had sufficient potential residual strength for use in exterior structural applications.
\end{abstract}

(C) 2005 Elsevier Ltd. All rights reserved.

Keywords: Nondestructive evaluation; Railroad tie; Creosote treatment; Residual strength

\section{Introduction}

Preservative-treated wooden railroad ties are important construction materials and generally exposed to varying and frequently strict conditions. This exposure can lead to deterioration resulting from decay, insect attack, weathering, mechanical damage, etc. Therefore, railroad ties must be monitored in order to maintain structural safety in service. Ross et al. [1] indicated that it is important to periodically examine wood structural components to determine the extent of degradation so that degraded members can be replaced or reinforced to avoid structural failure.

Railroad ties have long been a major disposal problem when removed after years of service. In general, many of these retired railroad ties are no longer useful because their wood structures are damaged. However, conservation ethics and wood resource shortages have often stimulated the adaptive reuse of old (demolished, retired, or historic)

\footnotetext{
${ }^{*}$ Corresponding author. Tel.: + $88623039978 \times 2604$; fax: +88623035738 .

E-mail address: d90625006@ntu.edu.tw (T.-H. Yang).
}

structural members. Shi et al. [2] indicated that the reuse of creosote-treated wood can greatly reduce landfill costs and is attractive both economically and environmentally. Therefore, a substantial amount of the interior sound wood can be reused for other exterior structural applications. A simple example of recycling preservative-treated wood includes the reuse of old railroad ties for landscape timbers. Thus, a concern affecting the reuse of wood resources is whether the quality of sawn timbers is sufficient for reuse. Obviously, the effective utilization of retired ties requires an understanding of their properties. Fridley et al. [3] reported that the effects of use and age on the mechanical properties of full-size timber members are not well understood and, therefore, complicate their reuse.

Wang et al. [4] indicated that a key component in determining reusability is the nondestructive evaluation (NDE) of the structural quality of the wood. During the past few decades, wood scientists have developed and used NDE tools for a wide range of applications, from woodbased materials to the evaluation of standing trees. For example, ultrasonic-wave and transverse vibration methods are two useful, nondestructive techniques for estimating the 
physical properties of a material. From these efforts evolved a hypothesis, founded on fundamental material properties, for establishing relationships among several NDE parameters and static mechanical properties and the density of wood products [5-10] However, studies have not addressed the use of these two NDE techniques to evaluate the potential quality of preservative-treated railroad ties retired from service. In addition, little information exists concerning relationships among the two NDE parameters and important residual strength properties of the ties.

Currently, there is interest in developing and using costeffective technologies to evaluate railroad ties removed from service. In particular, several studies have shown a good relationship between the dynamic modulus of elasticity and the static modulus of elasticity of wood members $[1,2,4,11-15]$. These promising results led us to hypothesize that the use of nondestructive techniques may be useful in assessing the potential quality of railroad ties removed after years of service.

Therefore, the objective of this study was to investigate the use of ultrasonic-wave and transverse vibration NDE methods, and a static bending test to assess the quality of wood (dynamic modulus of elasticity and residual strength) in retired creosote-treated wooden railroad ties.

\section{Materials and methods}

\subsection{Materials}

Total of 27 castoff creosote-treated wooden railroad ties was obtained from Taiwan Railroad Company. The dimension of these rectangular ties is approximately $14 \times 20 \times 215 \mathrm{~cm}$. These creosote-treated ties had been used as structural materials in railroad. The outer portions of the ties had been severely damaged mechanically or biologically after years of service. The major visual defects were decay, splits, insect borer damage, etc. These 27 ties were composed of seven species of local wood (Table 1).

\subsection{Experimental procedure}

A schematic of the experimental procedure is shown in Fig. 1. Longitudinal ultrasonic-wave NDE methods were used to assess the railroad ties. The ties were then sawn into lumber $(4 \times 12 \times 150 \mathrm{~cm})$. Ultrasonic-wave, transverse vibration NDE methods, and static bending tests were performed on the lumber. Next, ultrasonic-wave NDE methods and static bending tests were conducted on small clear specimens. The small clear specimens $(2 \times 2 \times 32 \mathrm{~cm})$ were obtained from the lumber.

\subsubsection{Ultrasonic-wave measurements}

The railroad ties, lumber, and specimens were analyzed using an ultrasonic-wave technique for longitudinal transmission; the ultrasonic-wave apparatus (Sylvatest, frequency $22 \mathrm{kHz}$; Swiss Products) used transmitting and receiving transducers.

The ultrasonic-wave velocity $(V)$ and the dynamic modulus of elasticity (MOEtu [tie], MOElu [lumber], and

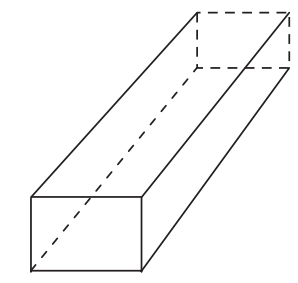

Railroad tie Ultrasonic wave

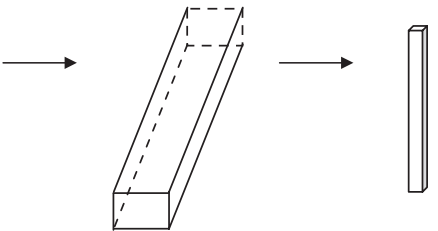

Lumber

Ultrasonic wave

Transverse vibration

Static bending
Small clear specimen Ultrasonic wave Static bending
Fig. 1. Schematic of experimental materials procedure.

Table 1

Physical characteristics and dynamic modulus of elasticity (MOEtu) of creosote-treated railroad ties removed after 20 years of service

\begin{tabular}{|c|c|c|c|c|c|c|}
\hline Species & Code & $\begin{array}{l}\text { Bulk density } \\
\left(\mathrm{kg} / \mathrm{m}^{3}\right)\end{array}$ & $\begin{array}{l}\text { Moisture content } \\
(\%)\end{array}$ & $\mathrm{Vt}(\mathrm{m} / \mathrm{s})$ & MOEtu (MPa) & $\begin{array}{l}\text { Number of railroad } \\
\text { ties }\end{array}$ \\
\hline Cyclobalanopsis longinux & $\mathrm{CL}$ & $\begin{array}{l}775.2 \\
(50)\end{array}$ & $\begin{array}{l}29.0 \\
(1.5)\end{array}$ & $\begin{array}{l}4213 \\
(603)\end{array}$ & $\begin{array}{l}13756.1 \\
(4747.7)\end{array}$ & 4 \\
\hline Schima superba & SS & $\begin{array}{l}559.3 \\
(80)\end{array}$ & $\begin{array}{l}32.3 \\
(4.5)\end{array}$ & $\begin{array}{l}3934 \\
(492)\end{array}$ & $\begin{array}{l}86537.0 \\
(2747.5)\end{array}$ & 7 \\
\hline Castanopsis carlesii & $\mathrm{CC}$ & $\begin{array}{l}577.8 \\
(50)\end{array}$ & $\begin{array}{l}31.0 \\
(3.7)\end{array}$ & $\begin{array}{l}4097 \\
(166)\end{array}$ & $\begin{array}{c}9700.6 \\
(1546.1)\end{array}$ & 3 \\
\hline Pasania harlandii & $\mathrm{PH}$ & $\begin{array}{l}620.0 \\
(35)\end{array}$ & $\begin{array}{l}31.3 \\
(1.0)\end{array}$ & $\begin{array}{l}4690 \\
(270)\end{array}$ & $\begin{array}{l}13638.4 \\
(1685.5)\end{array}$ & 3 \\
\hline $\begin{array}{l}\text { Koompassia } \\
\text { melaccensis }\end{array}$ & $\mathrm{KM}$ & $\begin{array}{l}692.2 \\
(47)\end{array}$ & $\begin{array}{l}32.9 \\
(1.0)\end{array}$ & $\begin{array}{l}4501 \\
(105)\end{array}$ & $\begin{array}{l}14022.5 \\
(1751.8)\end{array}$ & 3 \\
\hline Litsea acuminate & LA & $\begin{array}{l}434.0 \\
(298)\end{array}$ & $\begin{array}{l}36.4 \\
(6.1)\end{array}$ & $\begin{array}{r}3325 \\
(901)\end{array}$ & $\begin{array}{c}4796.7 \\
(4297.5)\end{array}$ & 4 \\
\hline Cyclobalanopsis gilvs & CG & $\begin{array}{l}561.6 \\
(176)\end{array}$ & $\begin{array}{l}37.1 \\
(1.9)\end{array}$ & $\begin{array}{l}3788 \\
(395)\end{array}$ & $\begin{array}{c}8058.2 \\
(3222.5)\end{array}$ & 3 \\
\hline
\end{tabular}

Vt, Ultrasonic-wave velocity of railroad tie; MOEtu, dynamic modulus of elasticity of tie by the ultrasonic-wave technique (at a moisture content of $12 \%$ ). Values in parentheses represent the standard deviation. 
MOEsu [specimen]) were calculated from the following formulas:

$V=\frac{L}{T}$, and

MOEtu, MOElu, or MOEsu $=V^{2} \times \rho$;

where $V$ is the ultrasonic-wave velocity in the direction parallel to the grain of the sample, $L$ is the distance between the two transducers, $T$ is the propagation time of the pulse from the transmitting transducer to the receiving transducer, MOEtu, MOElu, or MOEsu is dynamic modulus of elasticity in the direction parallel to the grain of the sample, and $\rho$ is the bulk density of the sample.

\subsubsection{Transverse vibration tests}

The transverse vibration technique was used to estimate the dynamic modulus of elasticity (MOElv) of the lumber obtained from the ties, using a Metriguard Model 340 E-computer. The test lumber was supported at one end by a knife-edge support and at the opposite end by a load-cell transducer. The dimensions of the lumber were physically measured, and then the load-cell transducer that was interfaced with the computer automatically determined its weight and natural frequency. The MOElv of the lumber was determined by the following equation $[4,12]$ :

MOElv $=\frac{\mathrm{fr}^{2} \times W \times L^{3}}{2.46 \times I \times g}$,

where MOElv is the modulus of elasticity determined by transverse vibration, fr is the natural frequency $(\mathrm{Hz}), W$ is the weight of the lumber $(\mathrm{g}), L$ is the span of lumber between supports $(\mathrm{cm}), I$ is the moment of inertia $\left(\mathrm{cm}^{4}\right)$ and $g$ is the gravitational constant $\left(9.8 \mathrm{~m} / \mathrm{s}^{2}\right)$.

\subsubsection{Static bending tests}

The static bending tests were conducted in accordance with ASTM D198 [16] (third-point loading method for lumber) and ASTM D143 [17] (center loading method for specimens), using a Shimadzu (Japan) UH-10A universaltype testing machine. All specimens were positioned flat (edgewise loading) for the bending tests. The proportional limit, ultimate load, and deflection were obtained from load-deflection curves, and the modulus of elasticity (MOEl [lumber], MOEs [specimen]) and modulus of rupture (MOR1 [lumber], MORs [specimen]) were calculated.

In this study, each sample's dynamic modulus of elasticity and bending property data were adjusted to single moisture content of $12 \%$ according to Wang et al [18] and Wang [19].

\section{Results and discussion}

\subsection{Physical properties}

Table 1 summarizes the physical characteristics of the creosote-treated railroad ties used in this study. Average moisture content values of the ties ranged from $29.0 \%$ to $37.1 \%$ and were close to or exceeded the fiber saturation point (about 30\%). In this experiment, according to the information provided by the Taiwan Railroad Company, all railroad ties had been in service for approximately 20 years. The small differences in moisture contents from tie to tie may imply similar service conditions or service histories. Wang et al. [4] indicated that older piles had higher moisture contents than newer piles and also exhibited greater moisture content changes in the radial direction than the newer piles. Comparisons of average moisture contents of the ties and the lumber obtained from them are shown in Tables 1 and 2. Average moisture contents of the lumber ranged from $28.6 \%$ to $37.7 \%$. This result indicated that the average moisture content values of ties were similar to those of the lumber. In other words, the outer layer, middle layer, and center of the ties all had similar mean moisture content values.

Bulk density is one of the most-common properties used to evaluate wood and is generally regarded as the mostimportant property of the wood, i.e., the property to which most other properties are strongly related. Bulk density values ranged from 434.0 to $775.2 \mathrm{~kg} / \mathrm{m}^{3}$ for the railroad ties, from 545.3 to $763.3 \mathrm{~kg} / \mathrm{m}^{3}$ for the lumber, and from 584 to $855.4 \mathrm{~kg} / \mathrm{m}^{3}$ for the small clear specimens (Tables 1-3). These results indicate that the mean bulk density values of ties were similar to those of the lumber. However, the small clear specimens had higher mean bulk density values than the ties and lumber. Moreover, the mean bulk density values of the ties and lumber were similar to that reported (Table 4) by Wang [20] and smaller than those of the specimens.

This may have been caused by creosote-treated performance and defect characteristics. This supports the hypothesis that creosote increases the bulk density, but defects (splits, seasoning checks, decay, and insect damage) decrease the density of the wood. The increasing effect was dependent on the depth and distribution of creosote penetration in the ties. Shi et al. [2] indicated that the measured densities of creosote-treated wood (Douglas fir and Southern pine) exceeded the values provided in the Timber Construction Manual (reference value). This result is reasonable because incorporating creosote preservative increases the wood weight.

The average bulk density values of the specimens were higher than those of the ties and lumber, because the specimens were clear and the ties/lumber contained defects. Therefore, the average bulk density values of specimens were mainly influenced (increased) by the creosote treatment; however, the ties and lumber were affected by the defects (decreases) and creosote (increases).

\subsection{Ultrasonic-wave propagation}

Average ultrasonic-wave speeds ranged from 3324.5 to $4690.1 \mathrm{~m} / \mathrm{s}$ for railroad ties, from 3547.5 to $4815.2 \mathrm{~m} / \mathrm{s}$ for the lumber, and from 4212.3 to $4982.8 \mathrm{~m} / \mathrm{s}$ for the small 
Table 2

Dynamic modulus of elasticity (MOE) and static bending properties of the lumber

\begin{tabular}{|c|c|c|c|c|c|c|c|c|}
\hline Code & $\begin{array}{l}\text { Bulk density } \\
\left(\mathrm{kg} / \mathrm{m}^{3}\right)\end{array}$ & $\mathrm{MC}(\%)$ & $\mathrm{Vl}(\mathrm{m} / \mathrm{s})$ & MOElu (MPa) & MOElv (MPa) & MOEl (MPa) & MORl (MPa) & $\begin{array}{l}\text { Number of } \\
\text { tested lumbers }\end{array}$ \\
\hline CL & $\begin{array}{l}763.3 \\
(56)\end{array}$ & $\begin{array}{l}29.7 \\
(1.8)\end{array}$ & $\begin{array}{l}4551 \\
(110)\end{array}$ & $\begin{array}{c}15811.0 \\
(1650.9)\end{array}$ & $\begin{array}{c}17778.6 \\
(3254.0)\end{array}$ & $\begin{array}{l}1258937 \\
(1116.3)\end{array}$ & $\begin{array}{c}67.2 \\
(11.5)\end{array}$ & 12 \\
\hline SS & $\begin{array}{l}552.2 \\
(83)\end{array}$ & $\begin{array}{l}34.0 \\
(3.4)\end{array}$ & $\begin{array}{l}4097 \\
(448)\end{array}$ & $\begin{array}{c}9270.5 \\
(2423.5)\end{array}$ & $\begin{array}{c}10138.7 \\
(1755.0)\end{array}$ & $\begin{array}{c}9258.8 \\
(1116.3)\end{array}$ & $\begin{array}{l}47.2 \\
(7.0)\end{array}$ & 28 \\
\hline $\mathrm{CC}$ & $\begin{array}{l}577.8 \\
(57)\end{array}$ & $\begin{array}{l}35.0 \\
(7.8)\end{array}$ & $\begin{array}{l}4207 \\
(126)\end{array}$ & $\begin{array}{c}10224.2 \\
(1173.1)\end{array}$ & $\begin{array}{r}14049.8 \\
(1087.9)\end{array}$ & $\begin{array}{c}9803.4 \\
(1323.6)\end{array}$ & $\begin{array}{l}67.6 \\
(6.2)\end{array}$ & 9 \\
\hline KM & $\begin{array}{l}715.4 \\
(38)\end{array}$ & $\begin{array}{l}28.6 \\
(2.2)\end{array}$ & $\begin{array}{r}4569 \\
(147)\end{array}$ & $\begin{array}{c}14937.8 \\
(1730.1)\end{array}$ & $\begin{array}{c}20262.5 \\
(2933.6)\end{array}$ & $\begin{array}{r}13995.0 \\
(445.8)\end{array}$ & $\begin{array}{c}103.9 \\
(3.4)\end{array}$ & 9 \\
\hline LA & $\begin{array}{l}545.3 \\
(123)\end{array}$ & $\begin{array}{l}30.2 \\
(2.5)\end{array}$ & $\begin{array}{l}3548 \\
(358)\end{array}$ & $\begin{array}{c}6862.4 \\
(2116.0)\end{array}$ & $\begin{array}{c}9912.0 \\
(4400.2)\end{array}$ & $\begin{array}{c}6035.4 \\
(1811.7)\end{array}$ & $\begin{array}{c}32.3 \\
(11.1)\end{array}$ & 16 \\
\hline $\mathrm{CG}$ & $\begin{array}{l}551.9 \\
(161)\end{array}$ & $\begin{array}{l}37.7 \\
(1.7)\end{array}$ & $\begin{array}{l}4121 \\
(470)\end{array}$ & $\begin{array}{c}9373.5 \\
(2316.2)\end{array}$ & $\begin{array}{r}12353.9 \\
(205.8)\end{array}$ & $\begin{array}{r}14318.9 \\
(579.2)\end{array}$ & $\begin{array}{r}130.4 \\
(4.8)\end{array}$ & 9 \\
\hline
\end{tabular}

V1, Ultrasonic-wave velocity of the lumber; MOElu, dynamic modulus of elasticity of the lumber by the ultrasonic-wave technique; MOElv, dynamic modulus of elasticity of the lumber by the transverse vibration technique; MOEl; modulus of elasticity of the lumber by the static bending test; MOR1, modulus of rupture of the lumber by the static bending test (at a moisture content of $12 \%$ ).

For codes, see Table 1.

Table 3

Dynamic modulus of elasticity (MOE) and static bending properties of specimens

\begin{tabular}{|c|c|c|c|c|c|c|}
\hline Code & Bulk density $\left(\mathrm{kg} / \mathrm{m}^{3}\right)$ & $\mathrm{Vs}(\mathrm{m} / \mathrm{s})$ & MOEsu (MPa) & MOEs (MPa) & MORs (MPa) & $\begin{array}{l}\text { Number of } \\
\text { specimens }\end{array}$ \\
\hline $\mathrm{CL}$ & $\begin{array}{l}855.4 \\
(45)\end{array}$ & $\begin{array}{l}4868 \\
(175)\end{array}$ & $\begin{array}{r}20269.9 \\
(2168.5)\end{array}$ & $\begin{array}{c}14927.6 \\
(2134.5)\end{array}$ & $\begin{array}{l}135.3 \\
(29.7)\end{array}$ & 56 \\
\hline SS & $\begin{array}{l}634.4 \\
(56)\end{array}$ & $\begin{array}{l}4304 \\
(457)\end{array}$ & $\begin{array}{c}11753.2 \\
(2688.7)\end{array}$ & $\begin{array}{c}8629.8 \\
(2406.0)\end{array}$ & $\begin{array}{c}87.7 \\
(31.8)\end{array}$ & 126 \\
\hline $\mathrm{CC}$ & $\begin{array}{l}651.4 \\
(48)\end{array}$ & $\begin{array}{l}4826 \\
(216)\end{array}$ & $\begin{array}{r}15168.7 \\
(1260.3)\end{array}$ & $\begin{array}{c}12143.2 \\
(1232.7)\end{array}$ & $\begin{array}{l}110.0 \\
(24.0)\end{array}$ & 48 \\
\hline $\mathrm{PH}$ & $\begin{array}{l}694.6 \\
(47)\end{array}$ & $\begin{array}{l}4983 \\
(106)\end{array}$ & $\begin{array}{c}17245.5 \\
(1139.5)\end{array}$ & $\begin{array}{c}13778.9 \\
(1041.2)\end{array}$ & $\begin{array}{l}129.9 \\
(20.7)\end{array}$ & 36 \\
\hline KM & $\begin{array}{l}755.2 \\
(56)\end{array}$ & $\begin{array}{l}4627 \\
(304)\end{array}$ & $\begin{array}{c}16168.3 \\
(2223.2)\end{array}$ & $\begin{array}{c}12549.3 \\
(2150.3)\end{array}$ & $\begin{array}{l}124.1 \\
(24.8)\end{array}$ & 36 \\
\hline LA & $\begin{array}{l}584.1 \\
(83)\end{array}$ & $\begin{array}{l}4212 \\
(321)\end{array}$ & $\begin{array}{c}10364.2 \\
(1893.4)\end{array}$ & $\begin{array}{c}7818.2 \\
(1807.0)\end{array}$ & $\begin{array}{c}81.9 \\
(22.2)\end{array}$ & 64 \\
\hline $\mathrm{CG}$ & $\begin{array}{l}788.8 \\
(101)\end{array}$ & $\begin{array}{l}4872 \\
(207)\end{array}$ & $\begin{array}{c}18725.6 \\
(3523.3)\end{array}$ & $\begin{array}{c}14139.9 \\
(4250.3)\end{array}$ & $\begin{array}{l}122.3 \\
(51.2)\end{array}$ & 36 \\
\hline
\end{tabular}

Vs, Ultrasonic-wave velocity of specimens; MOEsu, dynamic modulus of elasticity of specimens by the ultrasonic-wave technique; MOEs; modulus of elasticity of specimens by the static bending test; MORs, modulus of rupture of specimens by the static bending test (at a moisture content of $12 \%$ ).

For codes, see Table 1.

clear specimens (Tables 1-3). Ultrasonic-wave speeds measured in the lumber increased about $1.5-8.1 \%$ and increased $2.7-22.3 \%$ in specimens compared to those measured in the railroad ties. In other words, ultrasonic-wave speed showed the following trend: specimens $>$ lumber $>$ ties. Wang et al. [4] indicated that creosote attenuates stress-wave propagation and the attenuation effect is dependent on the depth of creosote penetration in the wood. Moreover, various defects such as splits, decay, and insect borer damage decrease ultrasonic wave speed in ties. Therefore, the average ultrasonic wave speed values were mainly influenced by the creosote and defect factors.
Table 4

Modulus of elasticity and modulus of rupture of 7 solid wood species published by Wang [20]

\begin{tabular}{llll}
\hline Code & $\begin{array}{l}\text { Bulk density } \\
\left(\mathrm{kg} / \mathrm{m}^{3}\right)\end{array}$ & $\begin{array}{l}\text { Modulus of } \\
\text { elasticity (MPa) }\end{array}$ & $\begin{array}{l}\text { Modulus of } \\
\text { rupture (MPa) }\end{array}$ \\
\hline CL & 767 & 14896 & 127.3 \\
SS & $491-514$ & $10339-13739.6$ & $98.8-104.1$ \\
CC & $607-749$ & $11760-14288.4$ & $54.7-59.8$ \\
PH & $531-598$ & $11965.8-16317$ & $133.1-150.3$ \\
KM & 930 & 2087.4 & 133.4 \\
LA & 441 & $8575-12348$ & $96.6-102.6$ \\
CG & 774 & 18228 & 191.5 \\
\hline
\end{tabular}

For codes, see Table 1. 


\subsection{Modulus of elasticity and modulus of rupture}

The average dynamic modulus of elasticity values (MOEtu) of railroad ties using ultrasonic-wave techniques are shown in Table 1. The MOEtu of ties ranged from 4796.7 to $14,022.5 \mathrm{MPa}$. The average dynamic modulus of elasticity values (MOElu and MOElv) of the lumber obtained from railroad ties using ultrasonic-wave and transverse vibration techniques are shown in Table 2. The MOElu of the lumber ranged from 6862.4 to $15,811.0 \mathrm{MPa}$ and the MOElv ranged from 7042.2 to $15,212.1 \mathrm{MPa}$. Static bending tests conducted on the lumber supported these results. The static modulus of elastic (MOEl) values for the lumber ranged from 6035.4 to 14,318.9 MPa. Values for the modulus of rupture (MOR1) ranged from 32.3 to $130.4 \mathrm{MPa}$ for the lumber. The average dynamic modulus of elasticity values (MOEsu) of specimens obtained from the lumber using ultrasonic-wave techniques are shown in Table 3. The MOEsu of specimens ranged from 10,364.2 to 20,269.9 $\mathrm{MPa}$. Static bending tests conducted on specimens supported these results. The static modulus of elastic (MOEs) values for the lumber ranged from 7818.2 to $14,927.6 \mathrm{MPa}$. Values for the modulus of rupture (MORs) ranged from 81.9 to $135.3 \mathrm{MPa}$ for the lumber.

In this experiment, the modulus of elasticity and modulus of rupture values of samples were below average reference values (Table 4) for 7 species of wood [20]. Some of the specimen property data showed that the wood quality was similar to reference values. This result was similar to that in the report of Leichti et al. [15], who indicated that the mean modulus of elasticity of specimens was approximately $85 \%$ of the Wood Handbook (reference value) stiffness value for green coastal Douglas fir. In other words, preservative-treated Douglas fir wood plies retain good wood quality.

In Tables 1-3, it was found that the MOEtu, MOElu, MOElv, MOEl, MORl, MOEsu, MOEs, and MORs values showed the following trend: specimens $>$ lumber $>$ ties. Furthermore, the MOElu (by the ultrasonic wave method) values were higher than those for MOElv (by the transverse vibration method). We consider that creosote and the defect characteristics are the most-important factors affecting the properties of the railroad ties. This is similar to the results of Shi et al. [2], who indicated that the outer layer of creosote-treated wood has a higher creosote concentration than the inner layers. In addition, the outer layers of the used wood may be damaged as a result of having been in service. Removal of both the outer layer and the defects should contribute to a larger strength in the sawn timber.

Therefore, it should be possible to remove part of the damaged outer layer of the ties and reuse the center or middle layers for exterior applications. Similar results have been reported for creosote-treated Douglas fir and Southern pine piles [4].

\subsection{Correlations among bulk density, ultrasonic wave speed, dynamic and static bending properties}

Correlations among several selected properties of railroad ties, lumber, and specimens could be represented by positive linear regression formulas and the coefficients of correlation $(r)$ obtained from these analyses are summarized in Table 5. Good correlations $(r=0.69-0.96, p<0.01)$ were found between NDE parameters and the static mechanical properties of ties, lumber and specimens. These results indicate that reasonably useful relationships exist

Table 5

Coefficients of relationships among the wood variables

\begin{tabular}{|c|c|c|c|c|c|c|c|c|c|c|c|c|c|c|c|}
\hline & & \multicolumn{3}{|c|}{ Railroad tie } & \multicolumn{6}{|c|}{ Lumber } & \multicolumn{5}{|c|}{ Specimen } \\
\hline & & $\mathrm{BDt}$ & $\mathrm{Vt}$ & MOEtu & $\mathrm{BDl}$ & $\mathrm{Vl}$ & MOElu & MOElv & MOEl & MOR1 & BDs & Vs & MOEsu & MOEs & MORs \\
\hline & & & 1 & $0.90^{* *}$ & 0.42 & $0.81 * *$ & $0.71 * *$ & $0.73 * *$ & $0.84^{* *}$ & $0.66 * *$ & 0.41 & $0.62^{* *}$ & $0.63^{* *}$ & $0.65^{* *}$ & $0.68 * *$ \\
\hline & MOEtu & & & 1 & $0.71 * *$ & $0.79 * *$ & $0.88 * *$ & $0.88^{* *}$ & $0.73 * *$ & $0.66 * *$ & $0.63 * *$ & $0.66^{* *}$ & $0.74 * *$ & $0.74 * *$ & $0.76^{* *}$ \\
\hline \multirow[t]{4}{*}{ Lumber } & $\mathrm{BDl}$ & & & & 1 & 0.44 & $0.80 * *$ & $0.72 * *$ & 0.22 & 0.28 & $0.78 * *$ & 0.44 & $0.67 * *$ & $0.61 * *$ & $0.61 * *$ \\
\hline & MOElv & & & & & & & 1 & $0.70^{* *}$ & $0.74 * *$ & $0.66 * *$ & $0.73^{* *}$ & $0.78^{* *}$ & $0.79 * *$ & $0.78 * *$ \\
\hline & MOEl & & & & & & & & 1 & $0.76^{* *}$ & $0.66^{*}$ & $0.89^{* *}$ & $0.83^{* *}$ & $0.87 * *$ & $0.92 * *$ \\
\hline & MORl & & & & & & & & & 1 & 0.52 & $0.84^{* *}$ & $0.73^{*}$ & $0.77 * *$ & $0.80^{* *}$ \\
\hline \multirow[t]{2}{*}{ Specimen } & BDs & & & & & & & & & & 1 & $0.72 * *$ & $0.94^{* *}$ & $0.79 * *$ & $0.75^{* *}$ \\
\hline & Vs & & & & & & & & & & & 1 & $0.91^{* *}$ & $0.90 * *$ & $0.83^{* *}$ \\
\hline
\end{tabular}

BDt, bulk density of railroad ties, BDl: bulk density of lumber, BDs: Bulk density of small clear specimens.

For other codes, see Tables 1-3.

$* * p<0.01$. 
among ultrasonic wave properties of ties, lumber, and specimens, the transverse vibration properties of the lumber, and corresponding flexural properties of the lumber and specimens. This observation of strong correlations is consistent with what other investigators have found for various wood materials using several NDE techniques. [4,11-12].

Schad et al. [11] reported that density is known to be the critical factor in railroad tie performance and durability. In this experiment, values of the MOR for the lumber and specimens increased with increasing bulk density, and the coefficients of correlation are summarized in Table 5. Good coefficients of correlation $(r=0.67-0.94, p<0.01)$ existed among the dynamic MOE and density values of ties, lumber, and specimens. However, lower coefficients of correlation $(r=0.22-0.79)$ were found between the static mechanical properties and density values of ties, lumber and specimens. Although, density is an important parameter for defining the strength and dynamic force, the effect of density on bending properties (MOE and MOR) and dynamic MOE in this study may have been caused by the creosote treatment and defect characteristics. Therefore, the bulk density values were weakly related to the static bending properties in samples.

Values of the dynamic MOE and bending properties of ties, lumber, and specimens increased with increasing ultrasonic wave velocity, and the relationships could be represented by positive linear regression formulas $(r=0.66-0.95, p<0.01$, as shown in Table 5), respectively. On the other hand, the relationships between ultrasonic velocity and bulk density are shown in Table 5 . The ultrasonic velocity tended to increase with increasing density, but the coefficients of correlation $(r=0.44-0.72)$ were lower. Hence, the ultrasonic velocity and bulk density values were weakly correlated in the samples.

The creosote increased the density and attenuated the ultrasonic wave/transverse vibration propagation in the wood, and the enlargement and attenuation effects were dependent on the depth and distribution of creosote penetration in the ties, respectively. In addition, the various defect traits decreased and weakened the density and ultrasonic wave/transverse vibration propagation in the wood.

Based on the above analyses and results, some of the variations in results may have been due to the creosote treatment and defect characteristics that had various degrees of impact on the ultrasonic-wave or transverse vibration properties of the wood.

\subsection{Residual strength rate}

In this paper, the actual values of MOEt and MORt of ties were not recorded in 20 years ago. Hence, the MOEt and MORt values were estimated by the credible regression formulas. The values of the MOE and MOR could be obtained by dynamic modulus properties, because the values of the MOEl and MORl increased linearly with
Table 6

Residual modulus of elasticity and modulus rupture rate (\%) of railroad ties

\begin{tabular}{lll}
\hline Code & $\begin{array}{l}\text { Residual modulus of } \\
\text { elasticity rate }(\%)\end{array}$ & $\begin{array}{l}\text { Residual modulus of } \\
\text { rupture rate }(\%)\end{array}$ \\
\hline CL & 77.8 & 60.9 \\
SS & 75.7 & 54.0 \\
CC & 72.6 & 56.9 \\
PH & 79.8 & 58.9 \\
KM & 71.5 & 79.3 \\
LA & 64.0 & 39.6 \\
CG & 38.9 & 25.4 \\
\hline
\end{tabular}

For codes, see Table 1.

increasing MOElu values and their relationships could be represented by the following positive linear regression formulas:

$$
\begin{aligned}
& \text { MOEl }=0.04 \text { MOElu }+94.8, \quad r=0.69^{* *} \text { and } \\
& \text { MORl }=0.65 \text { MOElu }+9944.7, \quad r=0.80^{* *}(p<0.01) .
\end{aligned}
$$

The values of MOEt and MORt could be obtained from the values of MOEtu, measured and calculated from railroad ties, substituted into Eqs. (1) and (2).

The residual modulus of elasticity rate (RMOE, \%) was calculated as

$\operatorname{RMOE}(\%)=\frac{\text { MOEt }}{\operatorname{MOEr}} \times 100$,

where MOEr is the referential (reference) modulus of elasticity [20], and MOEt is the calculated modulus of elasticity (from Eq. (1)).

The residual modulus of rupture rate (RMOR, \%) was calculated as

$\operatorname{RMOR}(\%)=\frac{\text { MORt }}{\operatorname{MORr}} \times 100$,

where MORr is the referential modulus of rupture [20], and MORt is the calculated modulus of rupture (from Eq. (2)).

In this experiment, the average RMOE values of ties ranged $38.9-79.8 \%$ and average RMOR values ranged $25.4-79.3 \%$ (Table 6). It was found that the modulus of elasticity and modulus of rupture values of samples were below average reference values [20]. Compared to the average reference values, the average residual modulus of elasticity rate of the lumber was $69 \%$ and that of specimens was $89 \%$. Moreover, the average residual strength rate of the lumber was $63 \%$ and specimen was $96 \%$. In other words, the MOEl, MOEs, MORl, and MORs values were about $31 \%, 11 \%, 37 \%$, and $4 \%$ lower than reference values [20].

\section{Conclusions}

Conservation ethics and wood resource shortages are generating increasing interest in reusing railroad ties 
removed after years of service. This study investigated the dynamic modulus of elasticity and residual strength of railroad ties removed after years of service by ultrasonicwave and transverse vibration methods, and static bending test, with the following results.

1. For these railroad ties removed after years of service, ultrasonic-wave speed showed the following trend: specimens $>$ lumber $>$ ties, and there was a good relationship existed between ultrasonic wave speed and bending properties in ties, lumbers and specimens.

2. There was a reasonably useful correlation between ultrasonic-wave- and transverse vibration-based modulus of elasticity values in ties and the corresponding static bending properties in the lumber and specimens. $(r=0.69-0.96, p<0.01)$

3. In these $2 \mathrm{NDE}$ technologies, it was found that the dynamic modulus of elasticity calculated by ultrasonicwave method (MOElu) was higher than that for MOElv (calculated by the transverse vibration method).

4. The residual MOE and MOR rate values of ties were ranged from 38.9 to $79.8 \%$ and 25.4 to $79.3 \%$, respectively, and it was found that the values of RMOE and RMOR for lumbers and specimens were higher than those of ties.

5. The railroad ties removed after years of service retained good quality wood in their inner layers. Therefore, lumber and specimens from these ties have the potential for use in exterior structural applications.

\section{Acknowledgments}

The authors thank the Taiwan Forest Research Institute and the National Science Council of Taiwan for financial support.

\section{References}

[1] Ross RJ, Pellerin RF, Forsman JW, Erickson JR, Lavinde JA. Relationship between stress wave transmission time and compressive properties of timbers removed from service. General Technical Report FPL-RN-0280. Forest Products Laboratory, Forest Service, US Department of Agriculture; 2001.

[2] Shi SQ, Gardner DJ, Pendlenton D, Hoffard T. Timber production from reclaimed creosote-treated wood pilings: economic analysis and quality evaluation. Forest Products Journal 2001;51(11/12):45-50.
[3] Fridley KJ, Michell JB, Hubt MO, Senft JF. Effects of 85 years of service on mechanical properties of timber members. Part 1 . Experimental results. Forest Products Journal 1996;46(5):85-96.

[4] Wang X, Ross RJ, Erickson JR, Forsman JW, Mcginnis GD, De Groot RC. Nondestructive evaluation of potential quality of creosote-treated piles removed from service. Forest Products Journal 2001;51(2):63-8.

[5] Peterson KR. The role of nondestructive evaluation in assuring the wise use of our timber resource. In: NDT 1994 ninth international symposium on the nondestructive testing of wood. 1994. p. 7-9.

[6] Bucur V. Acoustics of wood. Boca Raton, FL: CRC Press; 1995. p.185-192.

[7] Pellerin RF, Ross RJ. Nondestructive evaluation of wood. Forest Product Society, USA. 2002. p. 149-56.

[8] Ross RJ, Yang VW, Illman BL, Nelson WJ. Relationship between stress wave transmission time and bending strength of deteriorated oriented strandboard. Forest Products Journal 2003; 53(3):33-5.

[9] Ross RJ, Zerbe JI, Wang X, Green DW, Pellerin RF. Stress wave nondestructive evaluation of Douglas-fir peeler cores. Forest Products Journal 2005;55(3):90-4.

[10] Wang SY, Lin CJ, Chiu CM. Evaluation of wood quality of Taiwania trees grown with different thinning and pruning treatments using the ultrasonic-wave method. Wood Fiber Science 2005(2): 192-200.

[11] Schad KC, Kretschmann DE, McDonald KA, Ross RJ, Green DW. Stress wave techniques for determining quality of dimensional lumber from railroad ties. General Technical Report FPL-RN-0265. Forest Products Laboratory, Forest Service, US Department of Agriculture; 1995.

[12] Cai Z, Hunt MO, Ross RJ, Soltis LA. Static and vibration moduli of elasticity of salvaged and new joists. Forest Products Journal 2000; 50(2):35-40.

[13] Ross RJ, Hunt MO. Stress wave timing nondestructive evaluation tools for inspecting historic structures - a guide for use and interpretation. General Technical Report FPL-GTR-119. Forest Products Laboratory, Forest Service, US Department of Agriculture; 2000.

[14] Emerson R, Pollock D, Mclean D, Fridley K, Pellerin R, Ross RJ. Ultrasonic inspection of large bridge timbers. Forest Products Journal 2002;52(9):88-95.

[15] Leichti RJ, Meisenzahl M, Parry D. Structural timbers from retired Douglas-fir utility poles. Forest Products Journal 2005;55(3):61-6.

[16] American Society Testing and Materials. Methods D-198. Static test pf lumber in structural sizes. 1996.

[17] American Society Testing and Materials. Methods D-143. Small clear specimens of timber. 1996.

[18] Wang SY, Lin CJ, Chiu CM. The adjusted dynamic modulus of elasticity above the fiber saturation point in Taiwania plantation wood by ultrasonic-wave measurement. Holzforschung 2003;57: $547-52$.

[19] Wang SY. Wood physics. Taipei, Taiwan: National Institute for Compilation and Translation Press; 1986. p. 570.

[20] Wang SY. Commercial wood. Taipei, Taiwan: Taiwan Forest Product Association Press; 1995. p. 102-20, 183. 